\title{
Altitude of the Potentiometric Surface in the Mississippi River Valley Alluvial Aquifer, Spring 2018
}

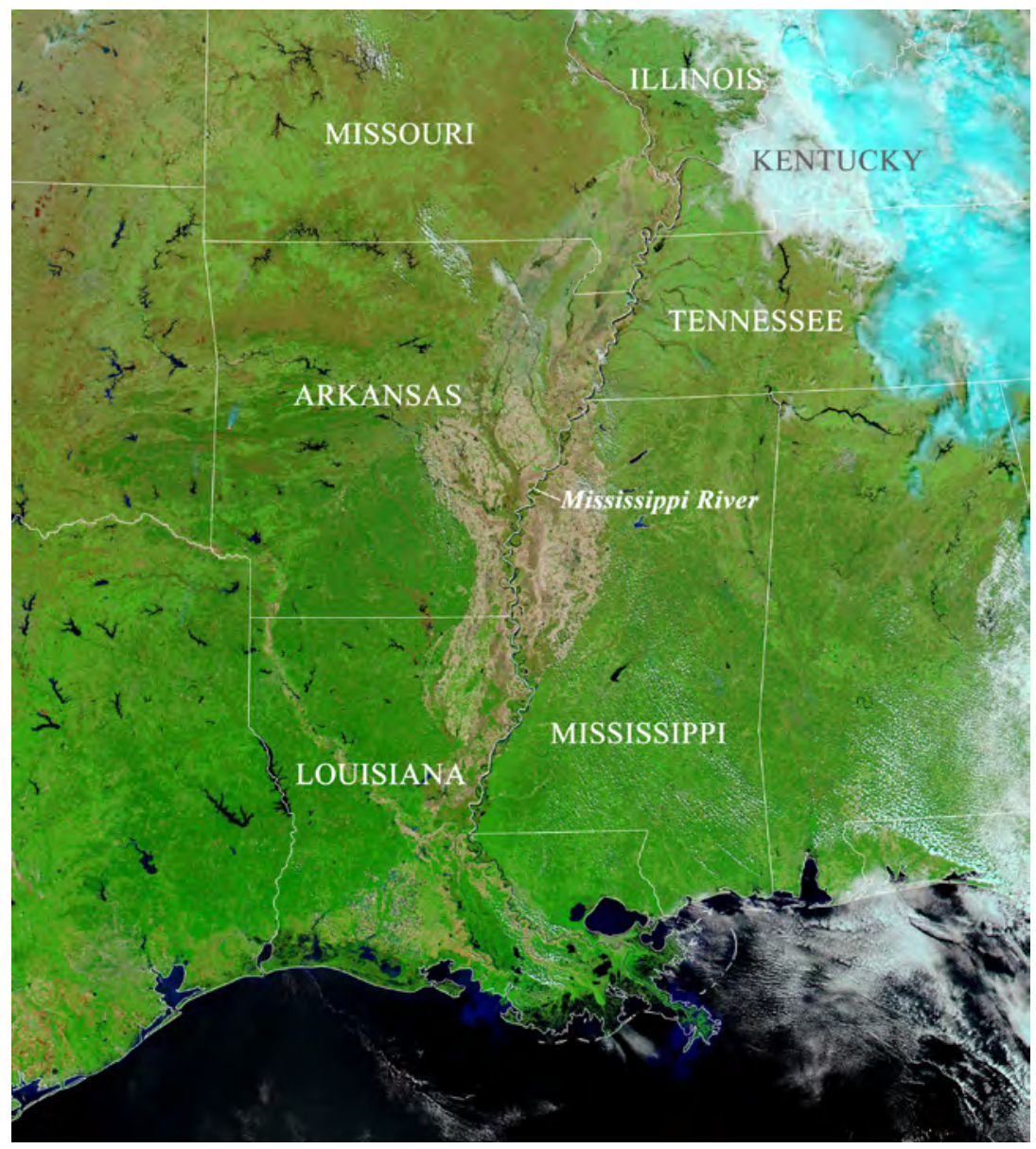

National Aeronautics and Space Administration (NASA) Earth Observatory images by Lauren Dauphin, using March 17, 2017, Moderate Resolution Imaging Spectroradiometer (MODIS) data from NASA Earth Observing System Data and Information System/Land, Atmosphere Near real-time Capability for EOS (EOSDIS/ LANCE) and Global Imagery Browse Services (GIBS) | Worldview.

Pamphlet to accompany

Scientific Investigations Map 3453 


\title{
U.S. Department of the Interior \\ DAVID BERNHARDT, Secretary
}

\author{
U.S. Geological Survey \\ James F. Reilly II, Director
}

U.S. Geological Survey, Reston, Virginia: 2020

For more information on the USGS - the Federal source for science about the Earth, its natural and living resources, natural hazards, and the environment-visit https://www.usgs.gov or call 1-888-ASK-USGS.

For an overview of USGS information products, including maps, imagery, and publications, visit https://store.usgs.gov/.

Any use of trade, firm, or product names is for descriptive purposes only and does not imply endorsement by the U.S. Government.

Although this information product, for the most part, is in the public domain, it also may contain copyrighted materials as noted in the text. Permission to reproduce copyrighted items must be secured from the copyright owner.

Suggested citation:

McGuire, V.L., Seanor, R.C., Asquith, W.H., Nottmeier, A.M., Smith, D.C., Tollett, R.W., Kress, W.H., and Strauch, K.R., 2020, Altitude of the potentiometric surface in the Mississippi River Valley alluvial aquifer, spring 2018:

U.S. Geological Survey Scientific Investigations Map 3453, 13 p., 5 sheets, https://doi.org/10.3133/sim3453.

Associated data for this publication:

McGuire, V.L., Seanor, R.C., Asquith, W.H., Nottmeier, A.M., Smith, D.C., Tollett, R.W., Kress, W.H., and Strauch, K.R., 2020, Datasets used to map the potentiometric surface, Mississippi River Valley alluvial aquifer, spring 2018:

U.S. Geological Survey data release, https://doi.org/10.5066/P992HD1R.

ISSN 2329-132X (online) 


\section{Acknowledgments}

This map is the culmination of efforts by personnel from the Arkansas Department of Health, Arkansas Geological Survey, Arkansas Natural Resources Commission, Illinois Department of Agriculture, Illinois State Water Survey, Louisiana Department of Natural Resources, Louisiana Department of Transportation and Development, Mississippi Department of Environmental Quality, Yazoo Mississippi Delta Joint Water Management District, Missouri Department of Natural Resources, U.S. Department of Agriculture-Natural Resources Conservation Service, U.S. Army Corps of Engineers, and the U.S. Geological Survey's Central Midwest, Lower Mississippi-Gulf, Oklahoma-Texas, and Nebraska Water Science Centers, who collected, compiled, organized, analyzed, and verified the groundwater- and surface-water-altitude data. In addition to the authors, who were primarily responsible for ensuring that the information contained in this report is accurate and complete, the following individuals contributed substantially to the review of the water-level data and related potentiometric-surface map:

- $\quad$ Mississippi Department of Environmental Quality: James Hoffmann, Kay Whittington, Sam Mabry, Madison Kymes, and Pat Phillips;

- U.S. Department of Agriculture, Agricultural Research Service: James Robert (JR)

Rigby; and

- $\quad$ Yazoo Mississippi Delta Joint Water Management District: David Kelly. 



\section{Contents}

Acknowledgments ….......................................................................................................................

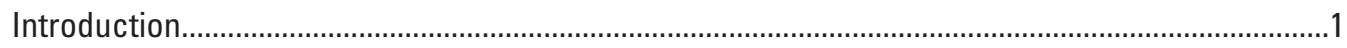

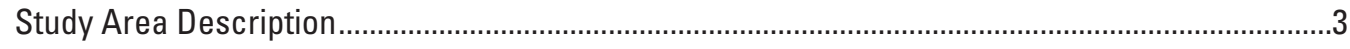

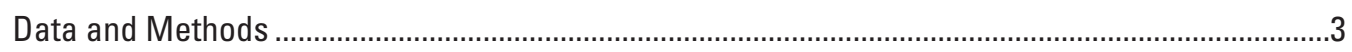

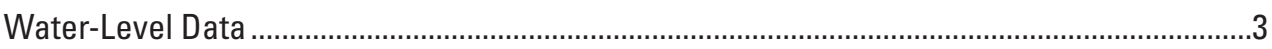

Characterizing the 2018 Potentiometric-Surface Raster and Contours ...................................8

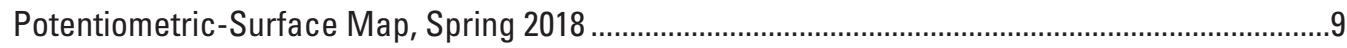

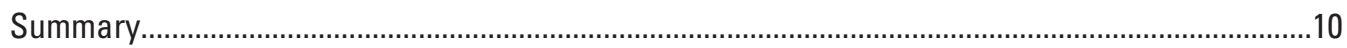

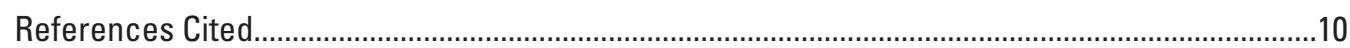

\section{Figures}

1. Map showing previous and current extent of the Mississippi River Valley alluvial aquifer and areas with insufficient groundwater-altitude data to map the potentiometric surface for spring 2018

2. Map showing location of wells with groundwater-altitude values and streamgages with surface-water-altitude values used to create the potentiometric-surface map of the Mississippi River Valley alluvial aquifer, spring 2018, and the part of the measurement month for the selected water-level-altitude value

\section{Tables}

1. Total number of wells that were completed in the Mississippi River Valley alluvial aquifer and measured manually one or more times or continually from January through May 2018, and the subset of these wells whose groundwater-altitude data were used to generate the potentiometric-surface map for the Mississippi River Valley alluvial aquifer, spring 2018, by Mississippi Alluvial Plain region.

2. Summary statistics for water-level measurement dates of water levels used in the spring 2018 potentiometric-surface map for wells that were completed in the Mississippi River Valley alluvial aquifer and measured manually one or more times or continually as part of groundwater monitoring networks from January through May 2018, by Mississippi Alluvial Plain region

3. Total number of streamgages in the Mississippi Alluvial Plain with surface-water-altitude values for April 10, 2018, and number of surface-water-altitude values, generally for April 10, 2018, used to generate the potentiometric-surface map, spring 2018, for the Mississippi River Valley alluvial aquifer by Mississippi Alluvial Plain region. 


\section{Conversion Factors}

U.S. customary units to International System of Units

\begin{tabular}{lcl}
\hline \multicolumn{1}{c}{ Multiply } & By & \multicolumn{1}{c}{ To obtain } \\
\hline foot $(\mathrm{ft})$ & Length & \\
mile $(\mathrm{mi})$ & 0.3048 & meter $(\mathrm{m})$ \\
& 1.609 & kilometer $(\mathrm{km})$ \\
\hline section $(640$ acres or 1 square mile) & Area & \\
square mile $\left(\mathrm{mi}^{2}\right)$ & 259.0 & square hectometer $\left(\mathrm{hm}^{2}\right)$ \\
square mile $\left(\mathrm{mi}^{2}\right)$ & 259.0 & hectare $($ ha) \\
\hline & 2.590 & square kilometer $\left(\mathrm{km}^{2}\right)$ \\
\hline million gallons per day $(\mathrm{Mgal} / \mathrm{d})$ & Flow rate & \\
\hline
\end{tabular}

\section{Datum}

Horizontal coordinate information is referenced to the World Geodetic Survey of 1984 (WGS 84). Historical data collected and stored as North American Datum of 1927 (NAD 27) or the North American Datum of 1983 (NAD 83) have been converted to WGS 84 for use in this publication.

Vertical coordinate information is referenced to the North American Vertical Datum of 1988 (NAVD 88). Historical data collected and stored as National Geodetic Vertical Datum of 1929 (NGVD 29) have been converted to NAVD 88 for use in this publication.

Altitude, as used in this report, refers to distance above the vertical datum.

\section{Abbreviations}

GIS geographic information system

MAP Mississippi Alluvial Plain

MRVA Mississippi River Valley alluvial

RMSE root mean square error

USGS U.S. Geological Survey 


\title{
Altitude of the Potentiometric Surface in the Mississippi River Valley Alluvial Aquifer, Spring 2018
}

\author{
By Virginia L. McGuire, Ronald C. Seanor, William H. Asquith, Anna M. Nottmeier, David C. Smith, \\ Roland W. Tollett, Wade H. Kress, and Kellan R. Strauch
}

\section{Introduction}

The Mississippi River Valley alluvial (MRVA) aquifer is an important surficial aquifer in the Mississippi Alluvial Plain (MAP) area. The aquifer is generally considered to be an unconfined aquifer (fig. 1; Clark and others, 2011), and withdrawals are primarily used for irrigation (Maupin and Barber, 2005). These groundwater withdrawals have resulted in substantial areas of water-level decline in parts of the aquifer. Concerns about water-level declines and the sustainability of the MRVA aquifer have prompted the U.S. Geological Survey (USGS), as part of the USGS Water Availability and Use Science Program and with assistance from other Federal, State, and local agencies, to undertake a regional wateravailability study to assess the characteristics of the MRVA aquifer, including the potentiometric-surface altitude of the MRVA aquifer for spring 2018, and to provide information to water managers to inform their decisions about resource allocations and aquifer sustainability.

The purpose of this report was to present a potentiometric-surface map for the MRVA aquifer using manually measured groundwater-altitude data and daily mean or maximum groundwater-altitude data from wells measured generally in spring 2018, which is after water levels have substantially recovered from pumping in the previous irrigation season and before pumping begins for the next irrigation season, and using the altitude of the top of the water surface in rivers in the area, hereinafter referred to as "surface-water altitude," generally on April 10, 2018, from streamgages in the area. The term "potentiometric surface" is used in this report because it is applicable for maps of the groundwater-altitude surface in unconfined, semiconfined, and confined aquifers (Lohman, 1972). In this report, the maps of the MRVA aquifer's groundwater surface are termed potentiometric-surface maps as opposed to water-table maps because, although the MRVA aquifer generally exhibits characteristics of unconfined conditions, where surface-water features may or may not be hydraulically connected, it also exhibits characteristics of confined or semiconfined conditions in some areas at least during part of the year. The location of these areas, where the aquifer is confined or semiconfined, is not well understood or defined (Arthur, 1994; Kleiss and others, 2000).
Previously published potentiometric-surface maps for a large part of the MRVA aquifer include maps from water levels measured from 1953 to 1961 (Krinitzsky and Wire, 1964), for 1964 (Boswell and others, 1968), and for 2016 (McGuire and others, 2019). Previously published potentiometric-surface maps for parts of the MRVA aquifer include maps for the Grand Prairie region in Arkansas in 1929, 1939, and 1959 (Engler and others, 1963) and selected counties in northeast and central Arkansas in 1965 and 1966 (Albin and others, 1967; Plebuch and Hines, 1967); the entire aquifer area in Arkansas for 1972, 1980, 1983, 1984, 1985, 1986, 1987, 1989, 1992, 1994, 1996, 1998, 2000, 2002, 2004, 2006, 2008, and 2012 (Ackerman, 1989; Edds and Fitzpatrick, 1984; Plafcan and Edds, 1986; Plafcan and Fugitt, 1987; Plafcan and Remsing, 1989; Westerfield, 1990; Westerfield and Gonthier, 1993; Westerfield and Poynter, 1994; Stanton and others, 1998; Joseph, 1999; Reed, 2004; Schrader, 2001, 2006, 2008, 2010, 2015); the aquifer area in northwestern Mississippi for various years including 1976, 1980, 1981, 1982, and 1983 (Dalsin, 1978; Wasson, 1980, Darden, 1981, 1982a, 1982b, 1983; Sumner, 1984, 1985; James Hoffmann, Mississippi Department of Environmental Quality, written commun., 2018); the entire aquifer area in Missouri for 1976 (Miller and Appel, 1997); and the part of the aquifer in northeastern Louisiana for 1990 (Seanor and Smoot, 1995). The previously published potentiometric-surface maps that were used in this study were Miller and Appel (1997), Seanor and Smoot (1995), Schrader (2015), and McGuire and others (2019).

To best reflect hydrologic conditions in the MRVA aquifer, the groundwater altitudes used to create the 2018 potentiometric-surface map would be measured in a short timeframe of days or 1 or 2 week(s) and there would be available data (for example, from sets of wells, with short [5 to 10 feet (ft)] screens, installed near the top, in the middle, and near the bottom of the aquifer) to indicate vertical flow components (Freeze and Cherry, 1979; Fetter, 2001). In fact, the measurement timing for many wells was determined by the needs and schedules of the entities doing the measurements instead of the preferred schedule for a regional potentiometricsurface map, and many of the measured wells had longer (greater than $10 \mathrm{ft}$ ) screens, so these water-level measurements tend to represent an average hydraulic head in the aquifer for 


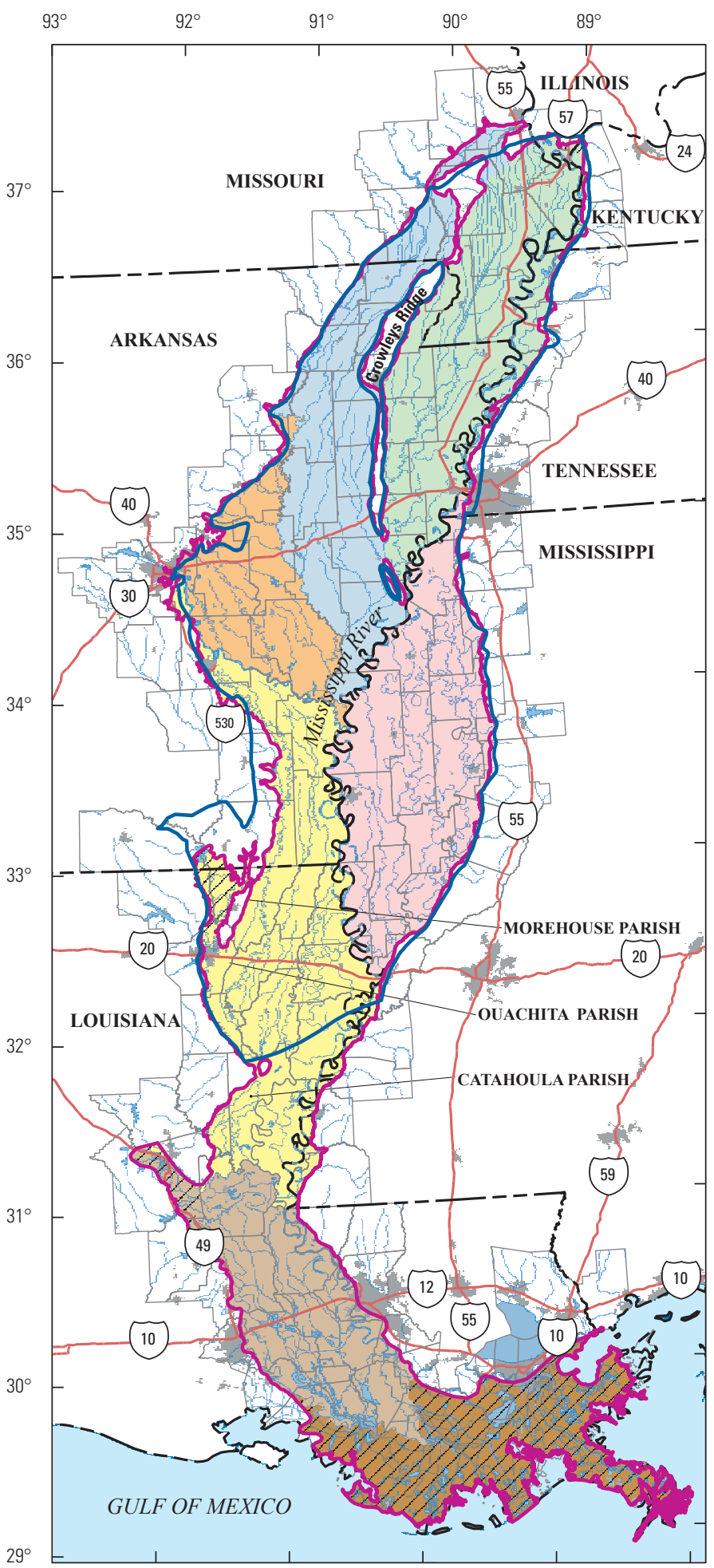

Base from U.S. Geological Survey digital data, 1:1,000,000 and 1:2,000,000 variously dated Highways from National Highway Planning Network, various scales, 2014 Urban areas from U.S. Census Bureau, 1:500,000, 2016

Albers National Hydrogeologic Grid projection

Standard parallels $45^{\circ} 30^{\prime} \mathrm{N}$. and $29^{\circ} 30^{\prime} \mathrm{N}$., central meridian $96^{\circ} 00^{\prime} \mathrm{W}$. World Geodetic Survey of 1984

\author{
EXPLANATION \\ Mississippi Alluvial Plain (MAP) region \\ St. Francis \\ Cache \\ Grand Prairie \\ Delta \\ Boeuf \\ Atchafalaya \\ Deltaic and Chenier Plains \\ Urban areas \\ $1 / /$, Areas of the MRVA aquifer with insufficient groundwater-altitude \\ data, spring 2018 \\ _ County or parish boundary—-Labels shown for selected parishes \\ Stream
MRVA aquifer extent (previous) \\ MRVA aquifer extent (current)
}
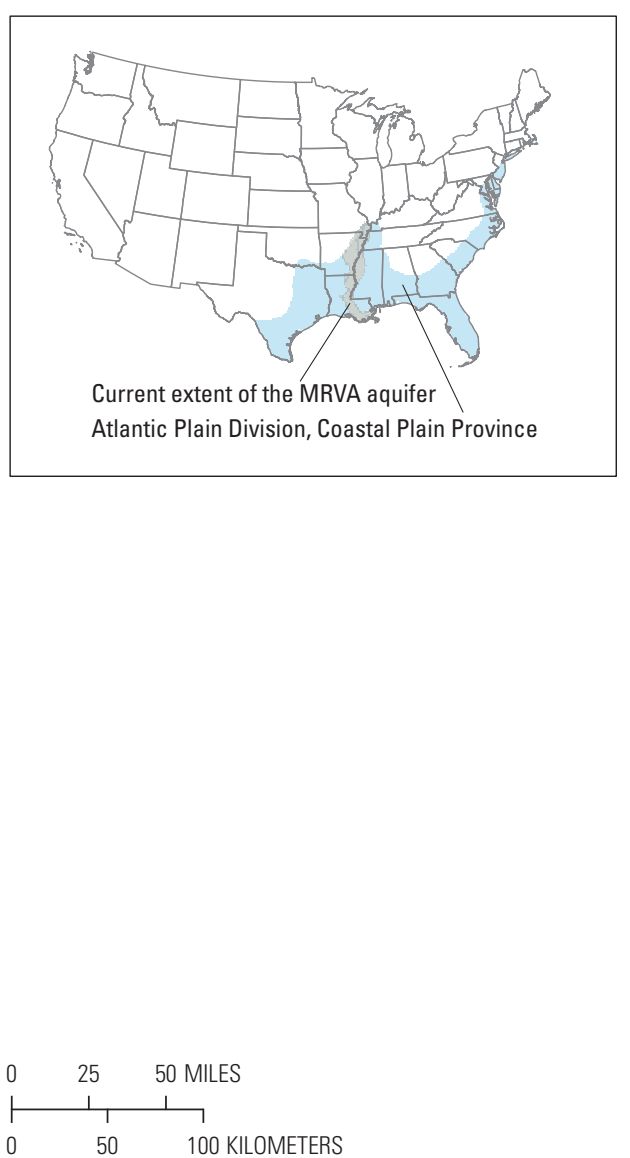

Previous extent of the MRVA aquifer (U.S. Geological Survey, 2015)

Current extent of the MRVA aquifer (Painter and Westerman, 2018)

Physiographic divisions (Fenneman and Johnson, 1946; U.S. Geological Survey, 2004) MAP regions (Ladd and Travers, 2019)

Figure 1. Previous and current extent of the Mississippi River Valley alluvial (MRVA) aquifer and areas with insufficient groundwater-altitude data to map the potentiometric surface for spring 2018. 
that location (Fetter, 2001). For this report, recognizing the limitations of the available data, it was decided to assess all available groundwater-altitude data from wells measured from January to May 2018 for use in the potentiometric-surface map for spring 2018. The resultant potentiometric-surface map would then represent the generalized central tendency for spring 2018, but it would not be useful for some purposes, such as for calibration of a groundwater-flow model for early April 2018 or for some local scale assessments.

\section{Study Area Description}

The current (2019) extent of the MRVA aquifer is defined to be the same as the boundary of the MAP physiographic division, which is a revision of the aquifer extent used in previous studies (fig. 1; Ackerman, 1996; Clark and others, 2011; Maupin and Barber, 2005; U.S. Geological Survey, 2015; Painter and Westerman, 2018). The MRVA aquifer underlies an area of approximately 43,800 square miles $\left(\mathrm{mi}^{2}\right)$ in parts of seven States-Arkansas, Illinois, Kentucky, Louisiana, Mississippi, Missouri, and Tennessee (fig. 1; Painter and Westerman, 2018).

The MRVA aquifer primarily underlies the Mississippi Alluvial Plain Section within the Atlantic Plain Division, Coastal Plain Physiographic Province (fig. 1; Fenneman and Johnson, 1946; U.S. Geological Survey, 2004). The MRVA aquifer extends about 560 miles (mi) north to south from southeastern Missouri and Illinois and southwestern Kentucky to the Gulf of Mexico off Louisiana. The width of the MRVA aquifer ranges from about $35 \mathrm{mi}$ in northeast Louisiana and southwest Mississippi to $134 \mathrm{mi}$ in southern Louisiana. The Mississippi River (fig. 1) is within the MRVA aquifer boundary except in southeast Louisiana, where the river is north of the aquifer boundary and overlies aquifers in Pleistocene-aged deposits in Louisiana and not the MRVA aquifer (Smoot, 1986). Where the Mississippi River is within the MRVA aquifer boundary, the river is along the eastern boundary of the northern and southern part of the aquifer; in the central part of the MRVA aquifer, the Mississippi River curves toward the middle of the aquifer at the northwest boundary of Mississippi before curving back toward the eastern boundary of the aquifer about $50 \mathrm{mi}$ south of the northeast boundary of Louisiana (fig. 1).

The MRVA aquifer is contained in Quaternary-age sand, gravel, silt, and clay deposits overlying Tertiary-age units (Hosman and Weiss, 1991; Saucier, 1994; Clark and others, 2011). In some areas, the MRVA aquifer is overlain by a Quaternary-age confining unit of silt and clay; where present, this confining unit impedes recharge to the MRVA aquifer (Ackerman, 1989; Boswell and others, 1968; Kleiss and others, 2000). There are four areas within the MRVA aquifer extent where the MRVA aquifer is not present (fig. 1; Painter and Westerman, 2018). The two northernmost areas, in northeastern Arkansas and southeastern Missouri, which are termed
"Crowleys Ridge," are erosional remnants of Tertiary-age deposits of clay, silt, sand, and lignite, overlaid by Quaternaryage sand and gravel, and capped by Quaternary-age loess (fig. 1; Guccione and others, 1986; McFarland, 2004). The Crowleys Ridge areas are about 1,053 $\mathrm{mi}^{2}$; the combined length of the two parts of Crowleys Ridge is about $185 \mathrm{mi}$ and the width ranges from less than a mile to about $21 \mathrm{mi}$. Crowleys Ridge forms a physical barrier to groundwater flow in the MRVA aquifer (Schrader, 2008, 2010, 2015; Kresse and others, 2014). Two other areas where the aquifer is not present are an upland area of about $128 \mathrm{mi}^{2}$ in northeastern Louisiana in the center of Morehouse Parish and the northeastern part of Ouachita Parish, and an upland area of about $21 \mathrm{mi}^{2}$ in the north-central part of Catahoula Parish (Saucier, 1994).

Groundwater withdrawals in 2000, from wells screened in the previously mapped extent of the MRVA aquifer (fig. 1; U.S. Geological Survey, 2015), averaged 9,290 million gallons per day (Mgal/d), making it the third most heavily pumped aquifer in the Nation (Maupin and Barber, 2005). More than 98 percent of total withdrawals in 2000 , from wells completed in the previously mapped extent of the aquifer, were for irrigation. Groundwater withdrawals associated with the revised extent (fig. 1; Painter and Westerman, 2018) of the MRVA aquifer have not been determined.

\section{Data and Methods}

The 2018 potentiometric-surface raster and associated contours were created by interpolating the groundwateraltitude data from wells and surface-water-altitude data from streamgages into a raster dataset (grid with a uniform cell size [about $0.386 \mathrm{mi}^{2}$ ] and hereinafter referred to as a "raster") and converting the resultant raster to contours using geographic information system (GIS) software (Esri® ArcMap, version 10.7; Esri, 2018). The method used to create the 2018 potentiometric-surface map is the same method used for the 2016 potentiometric-surface map (McGuire and others, 2019). The point shapefiles of groundwater- and surface-wateraltitude data, raster files of the potentiometric-surface map, and shapefile of the potentiometric-surface-altitude contours are available from McGuire and others (2020).

\section{Water-Level Data}

Groundwater-altitude data were compiled by the USGS (table 1; McGuire and others, 2020) from 1,126 wells completed in the MRVA aquifer and measured either manually or continually from January through May 2018. The wells were measured as part of a regular water-level monitoring program by the Arkansas Natural Resources Commission, Arkansas Department of Health, Arkansas Geological Survey, Illinois Department of Agriculture, Illinois State Water Survey, Louisiana Department of Natural Resources, Louisiana Department of Transportation and Development, Mississippi 
Department of Environmental Quality, Missouri Department of Natural Resources, Yazoo Mississippi Delta Joint Water Management District, U.S. Department of Agriculture-Natural Resources Conservation Service, and USGS. Wells measured by drillers in Missouri were included in the data used to map the potentiometric surface for the MRVA aquifer in 2016 (McGuire and others, 2019) but were not included for the 2018 potentiometric-surface map because the data from 2018 were not yet available (July 2019).

The groundwater altitude in wells that were manually measured one or more times is hereinafter referred to as "manually measured." The groundwater altitude in wells that were measured continually for all or part of the time period is hereinafter referred to as "continually measured." The manually and continually measured water levels were stored in the USGS National Water Information System database (U.S. Geological Survey, 2019a, 2019b) as depth to water below land surface. For the manually and continually measured wells, the land-surface altitude, in feet, and associated vertical datum (National Geodetic Vertical Datum of 1929 [NGVD 29] or North American Vertical Datum of 1988 [NAVD 88]) were retrieved or determined for each well. If the stored land-surface altitude datum was NGVD 29, the land-surface altitude was converted to NAVD 88 using the National Geodetic Survey's VERTCON computer program (Miller, 1999), and the measured groundwater altitude or daily mean groundwater altitude with respect to the NAVD 88 was calculated for each well. Groundwater altitudes from the well's measuring point for manually and continually measured wells are assumed accurate to the hundredths of a foot.

All groundwater-altitude data from manually and continually measured wells were reviewed to identify and exclude groundwater-altitude values that appeared to be affected by current or recent pumping and that were substantially different from the groundwater altitudes in nearby wells, possibly because of local or seasonal conditions. Other considerations for rejecting a well's groundwater altitude were apparent discrepancies between the spatial location of the well and the well's legal description or identifier and suspected inaccuracy in the land-surface altitude value. In addition, groundwateraltitude data from wells were not used for (1) wells that were flowing and could not be measured or (2) wells that were dry. Groundwater-altitude data from 46 of 1,144 manually measured wells and 2 of 30 continually measured wells were not used in the 2018 potentiometric-surface map (table 1; McGuire and others, 2020).

Groundwater-altitude data from 1,126 wells were used in the spring 2018 potentiometric-surface map. These wells included 1,052 manually measured wells, which were measured one time; 46 manually measured wells, which were measured two or four times; and 28 continually measured wells that were in operation for all or part of the time from January to May 2018 (table 1; McGuire and others, 2020). The median measurement date for the selected manually and continually measured water levels was April 10, 2018 (table 2). For manually measured wells with one measurement, the only available measurement was selected as the groundwater altitude to consider for use to create the potentiometric-surface map. For the manually measured wells with more than one measurement, the maximum (highest) groundwater altitude for each well was selected; the difference between the maximum and minimum groundwater-altitude values ranged from 0.00 to $13.86 \mathrm{ft}$, with a median difference of $1.03 \mathrm{ft}$. For the 28 wells measured continually and used in the potentiometric-surface map, the daily mean groundwater-altitude values for February 25, 2018 (1 well); April 9, 2018 (1 well); or April 10, 2018 (26 wells) were used. Values for wells measured continually on dates other than April 10, 2018, were used when measurements were not available for April 10, 2018.

The distribution of measurement dates for water levels ranges from 0 wells for the first 15 days in January 2018 to 706 wells in the first 15 days of April 2018 (fig. 2). This distribution indicates that if only wells measured in a short timeframe, such as the first 15 days in April 2018, were used to create the 2018 potentiometric-surface map, there would be larger areas with no groundwater-altitude data (fig. 2; table 2). To partially assess the variability in water levels by measurement date, the difference for each MAP region in the mean of the daily mean water-level measurements for the continually measured wells for February 10, 2018, were compared to the value for April 10, 2018, with the exception of one well that was not measured on February 10, 2018. The results were St. Francis region, 6 wells, $-3 \mathrm{ft}$; Cache region, 6 of the 7 wells, $-3 \mathrm{ft}$; Grand Prairie region, 4 wells, $0 \mathrm{ft}$; Delta region, 9 wells, $-3 \mathrm{ft}$; Boeuf region, 2 wells, $0 \mathrm{ft}$; and for 27 of the 28 wells, $-2 \mathrm{ft}$. These results indicate that water-level altitude on February 10 in the wells was approximately the same or lower than the water-level altitude on April 10.

Daily mean surface-water-altitude data were assembled for 104 streamgages routinely operated by the U.S. Army Corps of Engineers and the USGS in the MRVA aquifer area (table 3; U.S. Geological Survey, 2018; U.S. Army Corps of Engineers, 2018; McGuire and others, 2020). For this study, the streamgage altitude, in feet; the associated vertical datum (NGVD 29 or NAVD 88); and the daily mean river stage on April 10, 2018, were retrieved for each streamgage. If the vertical datum associated with the streamgage altitude was NGVD 29, the streamgage altitude was converted to NAVD 88 using National Geodetic Survey's VERTCON program (Miller, 1999) for possible use to create the potentiometric-surface map.

Of the 104 streamgages considered for use in the potentiometric-surface map (table 3), 25 were in areas with little or no groundwater data (defined as no groundwater data within $12.4 \mathrm{mi}$ of the center of the cell that contains the streamgages); 12 had surface-water altitudes that were much higher than the nearby wells screened in the MRVA aquifer, likely either because the surface-water altitude was affected by precipitation events or the MRVA aquifer is not connected to the surface water at these locations; and 1 had a surfacewater altitude that was much lower than the nearby well screened in the MRVA aquifer, possibly because the aquifer 
Table 1. Total number of wells that were completed in the Mississippi River Valley alluvial aquifer and measured manually one or more times or continually from January through May (pre-irrigation season) 2018, and the subset of these wells whose groundwater-altitude data were used to generate the potentiometric-surface map for the Mississippi River Valley alluvial aquifer, spring 2018, by Mississippi Alluvial Plain region (Ladd and Travers, 2019).

[MAP, Mississippi Alluvial Plain; --, no data]

\begin{tabular}{|c|c|c|c|c|c|}
\hline MAP Region & $\begin{array}{l}\text { Total number of wells } \\
\text { measured manually, pre- } \\
\text { irrigation season, } 2018\end{array}$ & $\begin{array}{c}\text { Total number of wells } \\
\text { measured continually, } \\
\text { pre-irrigation season, } 2018\end{array}$ & $\begin{array}{l}\text { Number of wells mea- } \\
\text { sured manually and used } \\
\text { in the potentiometric- } \\
\text { surface map, spring } 2018\end{array}$ & $\begin{array}{l}\text { Number of wells measured } \\
\text { continually and used in } \\
\text { the potentiometric-surface } \\
\text { map, spring } 2018\end{array}$ & $\begin{array}{c}\text { Total number of wells } \\
\text { used to generate the } \\
\text { potentiometric-surface } \\
\text { map, spring } 2018\end{array}$ \\
\hline St. Francis & 129 & 6 & 129 & 6 & 135 \\
\hline Cache & 137 & 7 & 131 & 7 & 138 \\
\hline Grand Prairie & 121 & 4 & 115 & 4 & 119 \\
\hline Delta & 462 & 11 & 462 & 9 & 471 \\
\hline Boeuf & 254 & 2 & 221 & 2 & 223 \\
\hline Atchafalaya & 41 & -- & 40 & -- & 40 \\
\hline Deltaic and Chenier Plains & -- & -- & -- & -- & -- \\
\hline Mississippi River Valley alluvial aquifer & 1,144 & 30 & 1,098 & 28 & 1,126 \\
\hline
\end{tabular}


Table 2. Summary statistics for water-level measurement dates of water levels used in the spring 2018 potentiometric-surface map for wells that were completed in the Mississippi River Valley alluvial aquifer and measured manually one or more times or continually as part of groundwater monitoring networks from January through May (referred to as spring) 2018, by Mississippi Alluvial Plain region (Ladd and Travers, 2019).

[Minimum, maximum, and median columns are shown in YYYYMMDD format; YYYY, year; MM, month; DD, day; MAP, Mississippi Alluvial Plain; --, no data]

\begin{tabular}{|c|c|c|c|c|c|c|c|c|c|}
\hline \multirow{3}{*}{ MAP Region } & \multicolumn{9}{|c|}{$\begin{array}{l}\text { Summary statistics for water-level measurement dates of water levels used in the potentiometric-surface map, } \\
\text { Mississippi River Valley alluvial aquifer, spring } 2018\end{array}$} \\
\hline & \multicolumn{3}{|c|}{$\begin{array}{c}\text { Manually measured wells in groundwater } \\
\text { monitoring networks }\end{array}$} & \multicolumn{3}{|c|}{ Continually measured wells } & \multicolumn{3}{|c|}{ All wells } \\
\hline & Minimum & Maximum & Median & Minimum & Maximum & Median & Minimum & Maximum & Median \\
\hline St. Francis & 20180305 & 20180523 & 20180410 & 20180410 & 20180410 & 20180410 & 20180305 & 20180523 & 20180410 \\
\hline Cache & 20180320 & 20180522 & 20180413 & 20180410 & 20180410 & 20180410 & 20180320 & 20180522 & 20180412 \\
\hline Grand Prairie & 20180124 & 20180516 & 20180412 & 20180410 & 20180410 & 20180410 & 20180124 & 20180516 & 20180411 \\
\hline Delta & 20180402 & 20180418 & 20180409 & 20180225 & 20180410 & 20180410 & 20180225 & 20180418 & 20180409 \\
\hline Boeuf & 20180205 & 20180503 & 20180402 & 20180409 & 20180410 & 20180410 & 20180205 & 20180503 & 20180402 \\
\hline Atchafalaya & 20180226 & 20180424 & 20180324 & -- & -- & -- & 20180226 & 20180424 & 20180324 \\
\hline Deltaic and Chenier Plains & -- & -- & -- & -- & -- & -- & -- & -- & -- \\
\hline Mississippi River Valley alluvial aquifer & 20180124 & 20180523 & 20180410 & 20180225 & 20180410 & 20180410 & 20180124 & 20180523 & 20180410 \\
\hline
\end{tabular}

Mississippi River Valley alluvial aquifer

20180124

20180523

20180410

(1) 


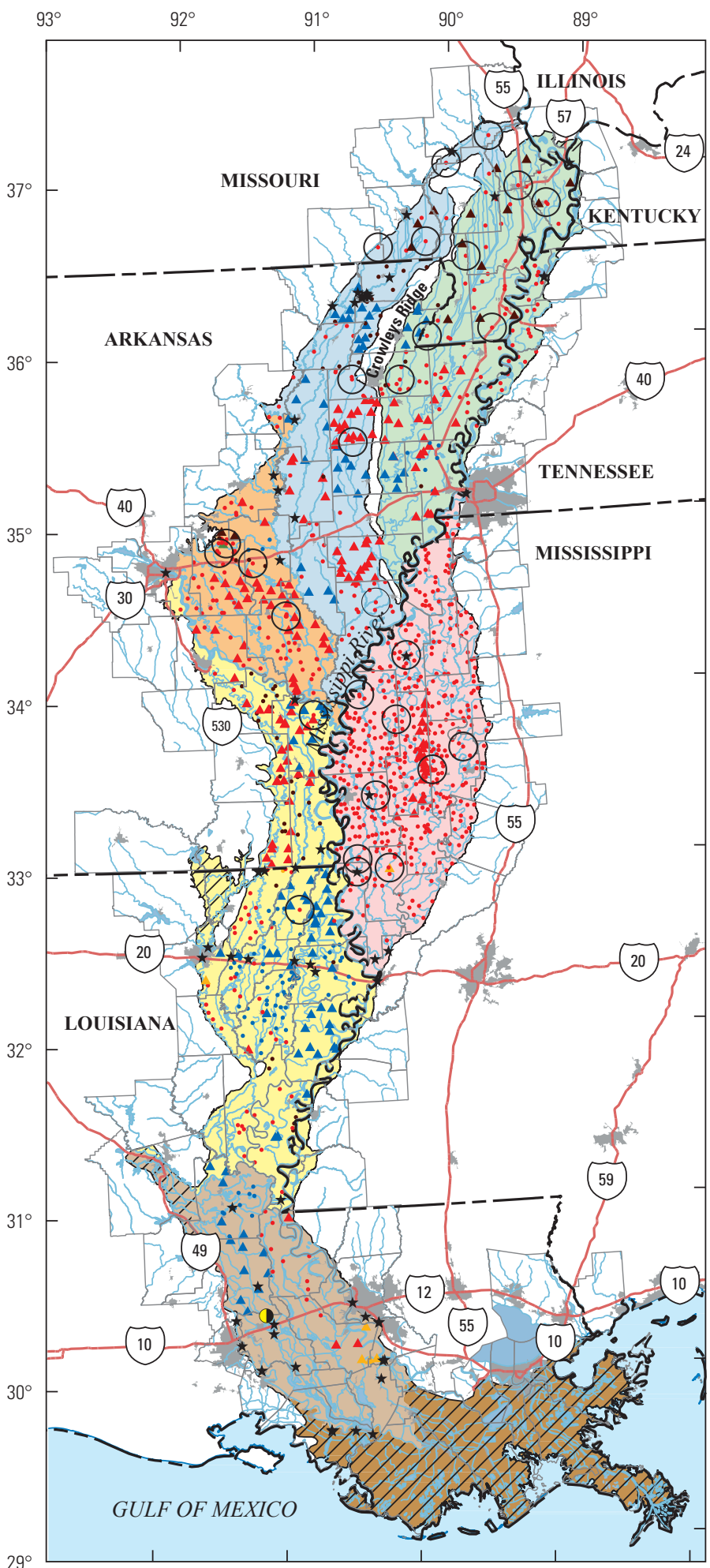

Base from U.S. Geological Survey digital data, 1:1,000,000 and 1:2,000,000 variously dated Highways from National Highway Planning Network, various scales, 2014 Urban areas from U.S. Census Bureau, 1:500,000, 2016

Albers National Hydrogeologic Grid projection

Standard parallels $45^{\circ} 30^{\prime} \mathrm{N}$. and $29^{\circ} 30^{\prime} \mathrm{N}$., central meridian $96^{\circ} 00^{\prime} \mathrm{W}$.

World Geodetic Survey of 1984

\section{EXPLANATION}

Mississippi Alluvial Plain (MAP) region

St. Francis

Cache

Grand Prairie

Delta

Boeuf

Atchafalaya

Deltaic and Chenier Plains

Urban areas

$1 /$, Areas of the MRVA aquifer with insufficient groundwater-altitude data, spring 2018

County or parish boundary

Stream

Location and measurement date of wells used in the spring 2018 potentiometric-surface map, MRVA aquifer, by part of month

Day 16 to end of month, January 2018 (1 well)

Day 1 to 15 , February 2018 (1 well)

Day 16 to end of month, February 2018 ( 6 wells)

Day 1 to 15, March 2018 (76 wells)

- Day 16 to end of month, March 2018 (105 wells)

- Day 1 to 15, April 2018 (706 wells)

- Day 16 to end of month, April 2018 (154 wells)

- $\quad$ Day 1 to 15, May 2018 (61 wells)

- Day 16 to end of month, May 2018 (16 wells)

Location and measurement date for steamgages used in the spring 2018 potentiometric-surface map, MRVA aquifer, by part of month

- Day 16 to end of month, January 2018 (1 streamgage)

$\star \quad$ Day 1 to 15, April 2018 (65 streamgages

Continuously measured well used in the spring 2018 potentiometric-surface map, MRVA aquifer

\section{$0 \quad 25 \quad 50$ MILES

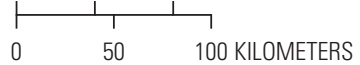

Current extent of the MRVA aquifer (Painter and Westerman, 2018) MAP regions (Ladd and Travers, 2019)

Well and streamgage locations and water-level-altitude measurement dates (U.S. Geological Survey, 2018, 2019a, 2019b)

Figure 2. Location of wells with groundwater-altitude values and streamgages with surface-water-altitude values used to create the potentiometric-surface map of the Mississippi River Valley alluvial (MRVA) aquifer, spring 2018, and the part of the measurement month for the selected water-level-altitude value. 
Table 3. Total number of streamgages in the Mississippi Alluvial Plain with surface-water-altitude values for April 10, 2018, and number of surface-water-altitude values, generally for April 10, 2018, used to generate the potentiometric-surface map, spring 2018, for the Mississippi River Valley alluvial aquifer by Mississippi Alluvial Plain region (Ladd and Travers, 2019).

[MAP, Mississippi Alluvial Plain; MRVA, Mississippi River Valley alluvial]

\begin{tabular}{lcc}
\hline \multicolumn{1}{c}{ MAP Region } & $\begin{array}{c}\text { Number of streamgaging stations with surface- } \\
\text { water-altitude values, generally for April 10, 2018, } \\
\text { in the MAP area }\end{array}$ & $\begin{array}{c}\text { Number of surface-water-altitude values, generally for } \\
\text { April 10, 2018, and used to generate the potentiometric- } \\
\text { surface map of 2018 for the MRVA aquifer }\end{array}$ \\
\hline St. Francis & 5 & 5 \\
Cache & 19 & 15 \\
Grand Prairie & 3 & 2 \\
Delta & 11 & 6 \\
Boeuf & 21 & 15 \\
Atchafalaya & 24 & 23 \\
Deltaic and Chenier Plains & 21 & 0 \\
\hline MRVA aquifer & 104 & 66 \\
\hline
\end{tabular}

is confined at the well location. There were 66 streamgages in areas with nearby groundwater-altitude data for 2018 (defined as groundwater data within $12.4 \mathrm{mi}$ of the center of the cell that contains the streamgages) used to create the 2018 potentiometric-surface map (fig. 2). The daily mean value was retrieved for January 15, 2018, for 1 streamgage; April 8, 2018, for 1 streamgage; April 9, 2018, for 1 streamgage; and April 10, 2018, for 63 streamgages. When a daily mean value was not available for April 10, 2018, the available daily mean value closest and prior to April 10, 2018, was retrieved and considered. The surface-water-altitude values were approximations of the groundwater altitude because the altitude where the groundwater and surface are connected likely is below the surface-water altitude and above the altitude of the river bottom.

The groundwater- and surface-water-altitude data were organized into two files (McGuire and others, 2020). Two fields were added to each groundwater- and surfacewater-altitude record in the files - the "USE_2018" and "USECMT2018" fields. The "USE_2018" field was assigned a positive value for records with a water-level altitude that was used in the creation of the potentiometric-surface map and a negative value for records that were excluded. For records where the "USE_2018" field is negative, the "USECMT2018" field is populated with a brief explanation for why the water level was not used for the 2018 potentiometric-surface map.

\section{Characterizing the 2018 Potentiometric-Surface Raster and Contours}

The potentiometric-surface raster and contours were generated using a series of GIS commands and source files of selected groundwater- and surface-water-altitude data from January to May 2018 (tables 1 and 3; McGuire and others, 2020). About 87 percent of the aquifer area had sufficient groundwater data for 2018 to create a potentiometric-surface map for spring 2018. The resultant spatial files are in Albers equal-area conic projection in meters using the World Geodetic Survey of 1984 and the potentiometric-surface altitude is expressed relative to NAVD 88. The rasters have a cell size of 1,000 meters and are aligned with the National Hydrologic Grid (Clark and others, 2018).

The steps used to generate the potentiometric-surface map for 2018 are described in the "Data and Methods" section for the report on the 2016 potentiometric-surface map (McGuire and others, 2019) and within the metadata for the raster and contours of the 2018 potentiometric-surface map (McGuire and others, 2020). A GIS was used to delineate the areas with little groundwater-altitude data for 2018 (McGuire and others, 2019); these areas total about $5,725 \mathrm{mi}^{2}$, or about 13 percent of the MRVA aquifer area.

The potentiometric-surface raster, which was output from the interpolation process using the GIS command "topo to raster," was compared to a raster of the aquifer base (Torak and Painter, 2019) to identify where the potentiometric-surface raster was below the aquifer-base raster. The potentiometricsurface raster was as much as $16 \mathrm{ft}$ below the aquifer-base raster in an area of about $44 \mathrm{mi}^{2}$ in the south-central part of Lonoke County, Arkansas. No changes were made to the potentiometric-surface raster as a result of this comparison because there were groundwater-altitude data for two wells thought to be screened in the MRVA aquifer, which indicates that the aquifer base warrants review for this area and that the well depth and screened interval for the two wells warrants investigation. The well identification code for these wells (termed "site badge" in the related data file; McGuire and others, 2020) are USSCS:344411091505001 and USSCS:344654091495401.

A total of five potentiometric maps were created-one for the entire MRVA aquifer, and one each for the St. Francis and Cache MAP regions in the north, Boeuf and Grand Prairie 
MAP regions in the west-central area, Delta MAP region in the east-central area, and Atchafalaya and Deltaic and Chenier Plains MAP regions in the south (Ladd and Travers, 2019). The maps are at a reduced, regional scale of 1:625,000 to allow for the display of control-point values.

The interpolation process, which was used to generate the rasters, can result in cell values for cells collocated with a measured well that are generally similar to, but commonly not equal to, the corresponding groundwater- and surfacewater-altitude values based on measurements. This difference is partly because the cell values represent the value for the cell area, and the measured values are values at specific locations within the area represented by the cell.

To assess the uncertainty in the final raster and contours, the water-level altitude for all values considered in the potentiometric-surface map and used to generate the potentiometric-surface raster were compared to the final potentiometric-surface raster value in the cell where the well or streamgage is located (McGuire and others, 2020). The root mean square error (RMSE) and bias were calculated for the difference between the manually- or continuallymeasured water-level altitude and the value extracted from the potentiometric-surface raster generated using the contours and point values (Helsel and Hirsch, 2002).

\section{Potentiometric-Surface Map, Spring 2018}

The spring 2018 potentiometric-surface contours ranged from 10 to $340 \mathrm{ft}$ above NAVD 88, and the regional direction of groundwater flow was to the south-southwest, except in areas of groundwater-altitude depressions (sheet 1), where groundwater flowed into the depression, and near rivers, where flow was generally parallel to the rivers. However, in some areas, flow was from the aquifer into the river or from the river into the aquifer. The lowest measured groundwater altitude was in Saint Landry Parish, Louisiana, and the highest was in Bollinger County, Missouri; the lowest measured surfacewater altitude was in Saint Mary Parish, La., and the highest was in Bollinger County, Mo. (sheet 1; McGuire and others, 2020). Based on groundwater- and surface-water-altitude measurements from January to May 2018, the MRVA aquifer is connected to surface-water features in some areas and disconnected in other areas at least during part of the year; however, the extent of the degree of connectivity of these areas cannot be derived from these data.

The RMSE for the differences between the measured water-level altitude and potentiometric-surface-raster value for the 46 manually and 2 continually measured wells, which were not used in the potentiometric-surface map and were located in a raster cell with a potentiometric-surface value, were 21 and $2 \mathrm{ft}$, respectively. The RMSE for the difference between the measured water-level altitude for the 1,126 manually and continually measured wells, which were used in the potentiometric-surface map and were located in a raster cell with a potentiometric-surface value, was $1.6 \mathrm{ft}$ with a bias of $-0.35 \mathrm{ft}$.

The spring 2018 potentiometric contours in the Cache region ranged from 110 to $340 \mathrm{ft}$ above NAVD 88 and show a large depression in the lower one-half of the Cache region (sheet 2). The lowest measured groundwater altitude was $108.50 \mathrm{ft}$ in a depression in Poinsett County, Ark., and the highest measured groundwater altitude was $339.30 \mathrm{ft}$ in Bollinger County, Mo.; the lowest measured surface-water altitude was $173.69 \mathrm{ft}$ in Prairie County, Ark., and the highest was $349.67 \mathrm{ft}$ in Bollinger County, Mo. (McGuire and others, 2020). Flow in the Cache region generally is to the south-southwest or into the depression in the southern part of the region.

The spring 2018 potentiometric contours in the St. Francis region ranged from 170 to $320 \mathrm{ft}$ above NAVD 88 (sheet 2). The lowest measured groundwater altitude was $163.00 \mathrm{ft}$ in Cross County, Ark., and the highest measured groundwater altitude was $316.40 \mathrm{ft}$ in Scott County, Mo.; the lowest measured surface-water altitude was $274.83 \mathrm{ft}$ in Lake County, Tennessee, and the highest was $316.91 \mathrm{ft}$ in Alexander County, Illinois (McGuire and others, 2020). Flow in the St. Francis region generally is to the south-southwest.

The spring 2018 potentiometric contours in the Boeuf region ranged from 30 to greater than $230 \mathrm{ft}$ above NAVD 88 (sheet 3). The lowest measured groundwater altitude was $27.38 \mathrm{ft}$ in Concordia Parish, La., and the highest measured groundwater altitude was $215.57 \mathrm{ft}$ in Pulaski County, Ark.; the lowest measured surface-water altitude was $36.46 \mathrm{ft}$ in Concordia Parish, La., and the highest was $231.27 \mathrm{ft}$ in Pulaski County, Ark. (McGuire and others, 2020). Flow in the Boeuf region is to the southeast, southwest, south, and into the depressions.

The spring 2018 potentiometric contours in the Grand Prairie region range from 90 to $230 \mathrm{ft}$ above NAVD 88; there is a large depression in the potentiometric surface within the region (sheet 3). The lowest measured groundwater altitude was $81.02 \mathrm{ft}$ in Arkansas County, Ark., and the highest measured groundwater altitude was $228.46 \mathrm{ft}$ in Independence County, Ark.; the lowest measured surface-water altitude was $194.17 \mathrm{ft}$ in White County, Ark., and the highest was $204.79 \mathrm{ft}$ in White County, Ark. (McGuire and others, 2020). Flow in the Grand Prairie region generally is into the depression that encompasses most of the region.

The spring 2018 potentiometric contours in the Delta region range from 60 to $210 \mathrm{ft}$ above NAVD 88; there is a large depression in the potentiometric surface within central part of the region (sheet 4). The lowest measured groundwater altitude was $59.18 \mathrm{ft}$ in Sunflower County, Mississippi, and the highest measured groundwater altitude was $199.54 \mathrm{ft}$ in DeSoto County, Miss.; the lowest measured surface-water altitude was $90.72 \mathrm{ft}$ in Warren County, Miss., and the highest was $211.79 \mathrm{ft}$ in Shelby County, Tenn. (McGuire and others, 2020). Flow in the Delta region generally is into the large depression at the center of the region. 
For most of the Atchafalaya region and all the Deltaic and Chenier Plains region, a spring 2018 potentiometric-surface map could not be created because there were no groundwateraltitude data (sheet 5). In the part of the Atchafalaya region included in the 2018 potentiometric-surface map, potentiometric contours ranged from 10 to $50 \mathrm{ft}$ above NAVD 88 (sheet 5). The lowest measured groundwater altitude was $4.07 \mathrm{ft}$ in Saint Landry Parish, La., and the highest measured groundwater altitude was $55.60 \mathrm{ft}$ in Avoyelles Parish, La.; the lowest measured surface-water altitude was $0.64 \mathrm{ft}$ in Saint Mary Parish, La., and the highest was $36.87 \mathrm{ft}$ in East Baton Rouge Parish, La. (McGuire and others, 2020). Groundwater flow in the mapped area is generally toward the south and southwest.

\section{Summary}

A potentiometric-surface map for spring 2018 was created for the Mississippi River Valley alluvial (MRVA) aquifer using available groundwater-altitude data from 1,126 wells completed in the MRVA aquifer and from the altitude of the top of the water surface in area rivers from 66 streamgages. Personnel from local, State, and Federal entities routinely collect groundwater-level data from wells screened in the MRVA aquifer. The U.S. Geological Survey and the U.S. Army Corps of Engineers routinely collect data on river stage and streamflow for the rivers overlying the MRVA aquifer area. The potentiometric-surface map for 2018 was created utilizing existing groundwater and surface-water altitudes to support investigations to characterize the MRVA aquifer as part of the U.S. Geological Survey Water Availability and Use Science Program.

Sufficient data were available to map the potentiometric surface of the MRVA aquifer for spring 2018 for about 87 percent of the aquifer area. The lowest measured groundwater altitude was $4.07 \mathrm{ft}$ in Saint Landry Parish, La., and the highest was $339.30 \mathrm{ft}$ in Bollinger County, Mo.; the lowest measured surface-water altitude was $0.64 \mathrm{ft}$ in Saint Mary Parish, La., and the highest was $349.67 \mathrm{ft}$ in Bollinger County, Mo. The potentiometric contours ranged from 10 to 340 feet above North American Vertical Datum of 1988. The regional direction of groundwater flow was generally to the southsouthwest, except in areas of groundwater-altitude depressions, where groundwater flowed into the depression, and near rivers, where flow can be from aquifer to the river or from the river into the aquifer. There are large depressions in the potentiometric-surface map in the lower one-half of the Cache region and in most of the Grand Prairie and Delta regions.

\section{References Cited}

Ackerman, D.J., 1989, Hydrology of the Mississippi River Valley alluvial aquifer, south-central United States - A preliminary assessment of the regional flow system: U.S. Geological Survey Water-Resources Investigations Report 88-4028, 74 p. [Also available at https://doi.org/10.3133/wri884028.]

Ackerman, D.J., 1996, Hydrology of the Mississippi River Valley alluvial aquifer, south-central United States: U.S. Geological Survey Professional Paper 1416-D, 53 p., 8 pls. [Also available at https://doi.org/10.3133/pp1416D.]

Albin, D.R., Hines, M.S., and Stephens, J.W., 1967, Water resources of Jackson and Independence Counties, Arkansas; Contributions to the Hydrology of the United States: U.S. Geological Survey Water-Supply Paper 1839-G, 29 p. [Also available at https://doi.org/10.3133/wsp1839G.]

Arthur, J.K., 1994, Thickness of the upper and lower confining units of the Mississippi River alluvial aquifer in northwestern Mississippi: U.S. Geological Survey Water-Resources Investigations Report 94-4172, 1 pl. [Also available at https://doi.org/10.3133/wri944172.]

Boswell, E.H., Cushing, E.M., Hosman, R.L., and Jeffery, H.G., 1968, Quaternary aquifers in the Mississippi embayment, with a discussion of quality of the water: U.S. Geological Survey Professional Paper 448-E, 15 p., 2 pls. [Also available at https://doi.org/10.3133/pp448E.]

Clark, B.R., Barlow, P.M., Peterson, S.M., Hughes, J.D., Reeves, H.W., and Viger, R.J., 2018, National-scale grid to support regional groundwater availability studies and a national hydrogeologic database: U.S. Geological Survey data release, https://doi.org/10.5066/F7P84B24.

Clark, B.R., Hart, R.M., and Gurdak, J.J., 2011, Groundwater availability of the Mississippi embayment: U.S. Geological Survey Professional Paper 1785, 62 p. [Also available at https://doi.org/10.3133/pp1785.]

Dalsin, G.J., 1978, The Mississippi River Valley alluvial aquifer in Mississippi: U.S. Geological Survey Water-Resources Investigations Report 78-106, 2 pls. [Also available at https://doi.org/10.3133/wri78106.]

Darden, D., 1981, Water-level map of the Mississippi delta alluvium in northwestern Mississippi, April 1981: U.S. Geological Survey Open-File Report 81-1123, 1 pl. [Also available at https://doi.org/10.3133/ofr811123.]

Darden, D., 1982a, Water-level maps of the alluvial aquifer, northwestern Mississippi, September 1981: U.S. Geological Survey Open-File Report 82-574, 1 pl. [Also available at https://doi.org/10.3133/ofr82574.] 
Darden, D., 1982b, Water-level maps of the alluvial aquifer, northwestern Mississippi, April 1982: U.S. Geological Survey Water-Resources Investigations Report 82-4061, 1 pl. [Also available at https://doi.org/10.3133/wri824061.]

Darden, D., 1983, Water-level maps of the alluvial aquifer, northwestern Mississippi, September 1982: U.S. Geological Survey Water-Resources Investigations Report 83-4133, 1 pl. [Also available at https://doi.org/10.3133/wri834133.]

Edds, J., and Fitzpatrick, D.J., 1984, Maps showing altitude of the potentiometric surface and changes in water levels of the alluvial aquifer in eastern Arkansas, Spring 1983: U.S. Geological Survey Water-Resources Investigations Report 84-4264, 1 pl. [Also available at https://doi.org/10.3133/wri844264.]

Engler, K., Bayley, F.H., III, and Sniegocki, R.T., 1963, Studies of artificial recharge in the Grand Prairie region, Arkansas; environment and history: U.S. Geological Survey-Water Supply Paper 1615-A, 32 p., 4 pls. [Also available at https://doi.org/10.3133/wsp1615A.]

Esri, 2018, ArcMap version 10.7: Redlands, Calif., Esri software documentation [online documentation and instructions included with GIS software]

Fenneman, N.M., and Johnson, D.W., 1946, Physical divisions of the United States (Map): Washington, D.C., U.S. Geological Survey, scale 1:7,000,000.

Fetter, C.W., 2001, Applied hydrology 4th ed.: New Jersey, Prentice-Hall, Inc., 598 p.

Freeze, R.A., and Cherry, J.A., 1979, Groundwater: Englewood Cliffs, New Jersey, 604 p.

Guccione, M.J., Prior, W.L., and Rutledge, E.M., 1986, The Tertiary and Quaternary geology of Crowley's Ridge-A guidebook: Arkansas Geological Commission Guidebook 86-4, 39 p.

Helsel, D.R., and Hirsch, R.M., 2002, Statistical methods in water resources: U.S. Geological Survey Techniques of Water-Resources Investigations 04-A3, 523 p. [Also available at https://doi.org/10.3133/twri04A3.]

Hosman, R.L., and Weiss, J.S., 1991, Geohydrologic units of the Mississippi embayment and Texas coastal uplands aquifer systems, south-central United States: U.S. Geological Survey Professional Paper 1416-B, 19 p. [Also available at https://doi.org/10.3133/pp1416B.]

Joseph, R.L., 1999, Status of water levels and selected waterquality conditions in the Mississippi River Valley alluvial aquifer in eastern Arkansas, 1998: U.S. Geological Survey Water-Resources Investigations Report 99-4035, 54 p. [Also available at https://doi.org/10.3133/wri994035.]
Kleiss, B.A., Coupe, R.H., Gonthier, G.J., and Justus, B.J., 2000, Water quality in the Mississippi embayment, Mississippi, Louisiana, Arkansas, Missouri, Tennessee, and Kentucky, 1995-98: U.S. Geological Survey Circular 1208, 36 p. [Also available at https://doi.org/10.3133/cir1208.]

Kresse, T.M., Hays, P.D., Merriman, K.R., Gillip, J.A., Fugitt, D.T., Spellman, J.L., Nottmeier, A.M., Westerman, D.A., Blackstock, J.M., and Battreal, J.L., 2014, Aquifers of Arkansas - Protection, management, and hydrologic and geochemical characteristics of groundwater resources in Arkansas: U.S. Geological Survey Scientific Investigations Report 2014-5149, 334 p. [Also available at https://doi.org/10.3133/sir20145149.]

Krinitzsky, E.L., and Wire, J.C., 1964, Groundwater in the alluvium of the lower Mississippi valley (Upper and Central Areas), v. 1-2: U.S. Army Corps of Engineers, Mississippi River Commission, Waterways Experiment Station, Vicksburg, Miss., Technical Report 3-658, v. 1, 100 p., v. 2, 377 p.

Ladd, D.E., and Travers, L.R., 2019, Generalized regions of the Mississippi Alluvial Plain: U.S. Geological Survey data release, accessed April 2019 at https://doi.org/10.5066/ P915ZZQM.

Lohman, S.W., 1972, Ground-water hydraulics: U.S. Geological Survey Professional Paper 708, 70 p. [Also available at https://doi.org/10.3133/pp708.]

Maupin, M.A., and Barber, N.L., 2005, Estimated withdrawals from principal aquifers in the United States, 2000: U.S. Geological Survey Circular 1279, 46 p. [Also available at https://doi.org/10.3133/cir1279.]

McFarland, J.D., 2004, Stratigraphic summary of Arkansas: Arkansas Geological Commission Information Circular $36,38 \mathrm{p}$.

McGuire, V.L., Seanor, R.C., Asquith, W.H., Kress, W.H., and Strauch, K.R., 2019, Altitude of the potentiometric surface in the Mississippi River Valley alluvial aquifer, spring 2016: U.S. Geological Survey Scientific Investigations Map 3439, 14 p., 5 sheets, accessed September 2019 at https://doi.org/10.3133/sim3439.

McGuire, V.L., Seanor, R.C., Asquith, W.H., Nottmeier, A.M., Smith, D.C., Tollett, R.W., Kress, W.H., and Strauch, K.R., 2020, Datasets used to map the potentiometric surface, Mississippi River Valley alluvial aquifer, spring 2018: U.S. Geological Survey data release, https://doi.org/10.5066/P992HD1R.

Miller, D.G., 1999, National Geodetic Survey (NGS) height conversion methodology: National Geodetic Survey's VERTCON program, accessed April 2018 at https:/www.ngs.noaa.gov/cgi-bin/VERTCON/vert_con.prl 
Miller, J.A., and Appel, C.L., 1997, Ground Water Atlas of the United States - Kansas, Missouri, and Nebraska: U.S. Geological Survey Hydrologic Atlas 730-D, 24 p. [Also available at https://doi.org/10.3133/ha730D.]

Painter, J.A., and Westerman, D.A., 2018, Mississippi alluvial plain extent, November 2017: U.S. Geological Survey data release, accessed March 2018 at https://doi.org/10.5066/ F70R9NMJ.

Plafcan, M., and Edds, J., 1986, Water level and saturated thickness maps of the alluvial aquifer in eastern Arkansas, 1984: U.S. Geological Survey Water-Resources Investigations Report 86-4014, 1 pl. [Also available at https://doi.org/10.3133/wri864014.]

Plafcan, M., and Fugitt, D.T., 1987, Water-level maps of the alluvial aquifer in eastern Arkansas, 1985: U.S. Geological Survey Water-Resources Investigations Report 86-4178, 1 pl. [Also available at https://doi.org/10.3133/wri864178.]

Plafcan, M., and Remsing, L.M., 1989, Water-level maps of the Mississippi River Valley alluvial aquifer in eastern Arkansas, 1986: U.S. Geological Survey Water-Resources Investigations Report 88-4067, 1 pl. [Also available at https://doi.org/10.3133/wri884067.]

Plebuch, R.O., and Hines, M.S., 1967, Water resources of Pulaski and Saline Counties, Arkansas: U.S. Geological Survey Water Supply Paper 1839-B, 25 p., 1 pl. [Also available at https://doi.org/10.3133/wsp1839B.]

Reed, T.B., 2004, Status of water levels and selected waterquality conditions in the Mississippi River Valley alluvial aquifer in eastern Arkansas, 2002: U.S. Geological Survey Scientific Investigations Report 2004-5129, 53 p. [Also available at https://doi.org/10.3133/sir20045129.]

Saucier, R.T., 1994, Geomorphology and quaternary geologic history of the lower Mississippi valley, Volumes I and II: Vicksburg, Mississippi, U.S. Army Corps Engineers Waterways Experiment Station, 414 p., 28 pls, accessed June 2018 at https://biotech.law.lsu.edu/climate/mississippi/ sausier/sausier.htm

Schrader, T.P., 2001, Status of water levels and selected waterquality conditions in the Mississippi River valley alluvial aquifer in eastern Arkansas, 2000: U.S. Geological Survey Water-Resources Investigations Report 2001-4124, 52 p., 2 pls. [Also available at https://doi.org/10.3133/wri014124.]

Schrader, T.P., 2006, Status of water levels and selected waterquality conditions in the Mississippi River Valley alluvial aquifer in eastern Arkansas, 2004: U.S. Geological Survey Scientific Investigations Report 2006-5128, 82 p., 3 pls. [Also available at https://doi.org/10.3133/sir20065128.]
Schrader, T.P., 2008, Water levels and selected water-quality conditions in the Mississippi River Valley alluvial aquifer in eastern Arkansas, 2006: U.S. Geological Survey Scientific Investigations Report 2008-5092, 73 p., accessed October 2019 at https://doi.org/10.3133/sir20085092.

Schrader, T.P., 2010, Water levels and selected water-quality conditions in the Mississippi River Valley alluvial aquifer in eastern Arkansas, 2008: U.S. Geological Survey Scientific Investigations Report 2010-5140, 71 p., 2 pls. [Also available at https://doi.org/10.3133/sir20105140.]

Schrader, T.P., 2015, Water levels and water quality in the Mississippi River Valley alluvial aquifer in eastern Arkansas, 2012: U.S. Geological Survey Scientific Investigations Report 2015-5059, 63 p., 2 pls., accessed June 2018 at https://doi.org/10.3133/sir20155059.

Seanor, R.C., and Smoot, C.W., 1995, Louisiana ground-water map no. 6-Potentiometric surface, 1990, and water-level changes, 1974-90, of the Mississippi River alluvial aquifer in northeastern Louisiana: U.S. Geological Survey WaterResources Investigations Report 95-4146, 2 pls., accessed June 2018 at https://doi.org/10.3133/wri954146.

Smoot, C.W., 1986, Louisiana hydrologic atlas map no. 2-Areal extent of freshwater in major aquifers of Louisiana: U.S. Geological Survey Water-Resources Investigations Report 86-4150, 1 pl., accessed July 2019 at https://doi.org/10.3133/wri864150.

Stanton, G.P., Joseph, R.L., and Pugh, A.L., 1998, Status of water levels and selected water-quality conditions in the Mississippi River Valley alluvial aquifer in eastern Arkansas, 1994-1996: U.S. Geological Survey WaterResources Investigations Report 98-4131, 72 p. [Also available at https://doi.org/10.3133/wri984131.]

Sumner, D.M., 1984, Water-level maps of the alluvial aquifer, northwestern Mississippi, April 1983: U.S. Geological Survey Water-Resources Investigations Report 83-4285, $1 \mathrm{pl}$. [Also available at https://doi.org/10.3133/wri834285.]

Sumner, D.M., 1985, Water-level maps of the alluvial aquifer, northwestern Mississippi, September 1983: U.S. Geological Survey Water-Resources Investigations Report 84-4346, $1 \mathrm{pl}$. [Also available at https://doi.org/10.3133/wri844346.]

Torak, L.J., and Painter, J.A., 2019, Digital surfaces of the bottom altitude and thickness of the Mississippi River Valley alluvial aquifer and site data within the Mississippi Alluvial Plain project region: U.S. Geological Survey data release, https://doi.org/10.5066/P9D9XR5F.

U.S. Army Corps of Engineers, 2018, RiverGages.com, Water levels of rivers and lakes: U.S. Army Corps of Engineers digital data, accessed August 2018 at https://rivergages.mvr.usace.army.mil/WaterControl/new/ layout.cfm 
U.S. Geological Survey, 2004, Physiographic divisions of the conterminous U.S.: U.S. Geological Survey digital data, accessed June 2018 at https://water.usgs.gov/GIS/dsdl/ physio_cov.zip

U.S. Geological Survey, 2015, Mississippi River Valley alluvial aquifer: U.S. Geological Survey digital data, accessed June 2018 at https://water.usgs.gov/GIS/dsdl/Mississippi River_Valley_alluvial_shp.zip

U.S. Geological Survey, 2018, USGS water data for the Nation: U.S. Geological Survey National Water Information System database, accessed August 2018 at https://dx.doi.org/10.5066/F7P55KJN.

U.S. Geological Survey, 2019a, USGS water data for the Nation: U.S. Geological Survey National Water Information System database, accessed April 2019 at https://dx.doi.org/10.5066/F7P55KJN.

U.S. Geological Survey, 2019b, USGS water data for the Nation: U.S. Geological Survey National Water Information System database, accessed November 2019 at https://dx.doi.org/10.5066/F7P55KJN.
Wasson, B.E., 1980, Water-level map of the Mississippi Delta alluvium in northwestern Mississippi, September 1980: Mississippi Bureau of Land and Water Resources Map 80-1, 1 pl.

Westerfield, P.W., 1990, Water-level maps of the Mississippi River Valley alluvial aquifer in eastern Arkansas, 1987: U.S. Geological Survey Water-Resources Investigations Report 90-4089, $1 \mathrm{pl}$. [Also available at https://doi.org/10.3133/wri904089.]

Westerfield, P.W., and Gonthier, G., 1993, Water-level maps of the Mississippi River Valley alluvial aquifer in eastern Arkansas, 1989: U.S. Geological Survey Water-Resources Investigations Report 92-4120, $1 \mathrm{pl}$. [Also available at https://doi.org/10.3133/wri924120.]

Westerfield, P.W., and Poynter, D.T., 1994, Water-level maps of the Mississippi River Valley alluvial aquifer in eastern Arkansas, spring 1992: U.S. Geological Survey Open-File Report 93-374, 1 pl. [Also available at https://doi.org/10.3133/ofr93374.] 

For more information about this publication, contact:

Director, USGS Nebraska Water Science Center 5231 South 19th Street Lincoln, NE 68512

402-328-4100

For additional information, visit: https://www.usgs.gov/centers/ne-water

Publishing support provided by the Rolla and Pembroke Publishing Service Centers 


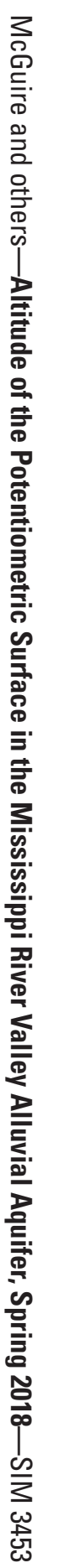

